\title{
Removal of Nitrate in the Aqueous Phase Using Granular Ferric Hydroxide
}

\author{
Mansooreh Dehghani ${ }^{1, *}$; Ebrahim Haidari ${ }^{1}$; Samaneh Shahsavani ${ }^{1}$; Narges Shamsedini ${ }^{1}$ \\ ${ }^{1}$ Department of Environmental Health Engineering, Shiraz University of Medical Sciences, Shiraz, IR Iran \\ *Corresponding author: Mansooreh Dehghani, Department of Environmental Health Engineering, Shiraz University of Medical Sciences, Shiraz, IR Iran. Tel: +989171184449, \\ Fax:+987137260225, E-mail: mdehghany@sums.ac.ir
}

Received: December 26, 2014; Revised: March 16, 2015; Accepted: April 2, 2015

\begin{abstract}
Background: In recent years, the nitrate concentration in surface water and especially in groundwater was increased significantly in many parts of Iran.

Objectives: The main objectives of this study were to evaluate the feasibility of using granular ferric hydroxide (GFH) to remove nitrate from aqueous phase as well as to determine the removal efficiency at the optimal condition.

Materials and Methods: The present study was conducted on a bench scale experiment. The spectrophotometer DR5000 (wavelength $520 \mathrm{~nm}$ ) was used to determine the nitrate concentration. The effect of influencing parameters including pH at 5 levels (3.8 - 7.8), initial nitrate concentration at 4 levels $(50-150 \mathrm{mg} / \mathrm{L})$ the amount of adsorbent dose $(0.625,1.25,2.5,3.75 \mathrm{~g} / 50 \mathrm{~mL})$, the effects of interfering ions, such as sulfate ions at 4 levels $(200-800 \mathrm{mg} / \mathrm{L})$ and chloride ions at 4 levels $(200-800 \mathrm{mg} / \mathrm{L})$, and contact time at 3 levels (30 - 90 minutes) were studied.

Results: Based on our data, $\mathrm{pH}$ of 4.8, adsorbent dose of $3.75 \mathrm{~g}$ and contact time of 90 minutes is optimal for nitrate removal. Furthermore, the nitrate reduction rate was increased rapidly by the addition of the adsorbent and decreased by nitrate addition. The nitrate reduction rate was increased by increasing the contact time. The percent of nitrate reduction was significantly enhanced by decreasing the $\mathrm{pH}$ (from 7.8 to 8.4 ) and then reached a plateau with a relative slow equilibration. Moreover, adsorption efficiency was significantly decreased in the presence of interfering ions, such as sulfate and chloride ions.

Conclusions: In conclusion, GFH can be used as a reliable and appropriate method with high efficiency for the reduction of nitrate in many polluted water resources.
\end{abstract}

Keywords: Nitrates; Ferric Hydroxide; Groundwater

\section{Background}

Nitrogen is one of the most important elements in nature and nitrate has the highest oxidation state (1). Nitrate contamination may occur through natural or anthropogenic sources. Elevated levels of nitrate in groundwater resources result from the excessive use of chemical fertilizers, uncontrolled discharges of municipal and industrial wastewater, human and animal waste, and erosion of natural deposits. Both nitrate and nitrite are present in the aquatic environment and can be converted rapidly from one form to another (2).

Organic and inorganic nitrogen is converted to nitrate by many processes such as mineralization, hydrolysis and bacterial nitrification. Nitrate ions are not absorbed by plants and leached through the soil easily. Basically, the high nitrate concentration in groundwater may be due to its high water solubility and mobility that often leads to nitrate leaching readily into groundwater sources and make them susceptible for the contamination. Nitrate contamination is more significant in those regions with low rainfall and poor vegetation cover. Therefore, surface and particularly groundwater resources may have a high level of nitrate pollution (3). Agricultural runoff and improper disposal of domestic wastewater may release a high level of nitrate into the groundwater as well. Moreover, more than $60 \%$ of freshwater consumption in Iran is supplied from groundwater. In arid and semi-arid areas the water shortage is an important issue (4). Therefore, the contamination of water resources with nitrate may limit the water supplies.

According to World Health Organization (WHO), drinking water must contain no more than $50 \mathrm{mg} / \mathrm{L}$ of nitrate (5) and Environmental Protection Agency (EPA) established a maximum contaminant level (MCL) of $45 \mathrm{mg} / \mathrm{L}$. European community recommends NO3- levels of 25 $\mathrm{mg} / \mathrm{L}$ (6-8). Moreover, WHO suggested the MCL of nitrite for the short and long-term exposure is 3 and $0.2 \mathrm{mg}$ $\mathrm{NO}_{2} / \mathrm{L}$, respectively. The revised WHO guidelines (2004) suggested that the sum of nitrite concentration ratio should not be greater than 1(3).

Excess of nitrate concentration can cause several hygienic and environmental impacts (5). High nitrate concentrations in water can cause methemoglobinemia or blue baby. Other side effects of high concentration of

Copyright (C) 2015, Ahvaz Jundishapur University of Medical Sciences. This is an open-access article distributed under the terms of the Creative Commons Attribution-Non Commercial 4.0 International License (http://creativecommons.org/licenses/by-nc/4.0/) which permits copy and redistribute the material just in noncommercial usages, provided the original work is properly cited. 
nitrate are as follows: interfere with the thyroid, hypertension, and insulin-dependent diabetes (6). Gastrointestinal cancer and the risk of miscarriage were also cited. Drinking water with high nitrate levels can increase the risk of ovarian cancer and bladder (7). Nitrate is one of the major sources of water contamination and is considered as a serious threat to aquatic ecosystems. Eutrophication for the aquatic ecosystems is considered to be toxic to animal and public health (8).

In general, nitrate can be removed through various methods, such as ion exchange (9), reverse osmosis (10), biological denitrification (11), electrocoagulation process (12). Nowadays, the adsorption process is widely used for the treatment of the waters contaminated by organic and inorganic contaminants (13). The most advantages of the adsorption technique include effectiveness, selectivity, regenerability, and cost efficiency (14). Moreover, activated carbon is considered as an effective adsorbent for removing the contaminant in aqueous environments due to its porous structure and large specific surface area, high removal efficiency and the feasibility of using in large scales $(15,16)$. However, one of the limitations of using the adsorption process is the transfer of pollutions from one media to another. Therefore, another method should be developed to remove the pollutions from the adsorbent. Numerous studies have demonstrated that the presence of natural and anthropogenic contaminants in water can significantly reduce the adsorption capacity of granular activated carbon. Therefore, background water quality affects its removal efficiency. Moreover, desorption is an important phenomena when designing adsorption process to remove the pollutions (17). The nitrate removal from water is accomplished using various adsorbents such as resins, activated carbon, clays, zeolites, pine bark, and walnuts (18). The study by Malakootian et al. (19) indicated that nano zero-valent iron was a reliable adsorbent for nitrate removal and fitted well by Ferundlich and Langmuir isotherm models (2). Demiral and Gunduzoglu used activated carbon prepared from sugar beet bagasse to remove nitrate from aqueous solution. Nitrate adsorption kinetics in aqueous solution closely followed Langmuir models (20).

Although granular ferric hydroxide (GFH) has some disadvantages, such as adding iron to water and the relatively high cost (21), it is used as an adsorbent for the removal of pollutants (22). The results of one study showed that the maximum adsorption capacity of GFH for the removal of nitrate and nitrate was achieved just in 2 to 3 minutes with the second order adsorption kinetics (4). Moreover, another study demonstrated that optimal condition for the removal of arsenic was at $\mathrm{pH}$ of 7.5 and contact time of 30 minutes (23). The combination of advanced oxidation process $\left(\mathrm{Fe} / \mathrm{H}_{2} \mathrm{O}_{2}\right)$ and adsorption on activated carbon was able to effectively reduce nitrate to $90 \%$ (24). Also, the highest removal of nitrate from groundwater using activated carbon such as rice bran, sludge from food industry and commercial activated carbon was at $\mathrm{pH}=4$ and the contact time of 4 hours (25). In addition, many studied have used GFH for the removal of arsenate and arsenide (26), fluoride (27), chromium (28) and phosphonate (29).

Since Fars is an agricultural province in Iran and enjoys the top rank in crop production such as wheat and maize in the country in recent years, many fertilizers especially ammonium nitrate and urea have been widely used in agricultural fields. Nitrate contamination in drinking water resources is an increasingly important problem in Iran. Elevated levels of nitrate in groundwater sources make the groundwater unsuitable for drinking without any treatment. The nitrate levels in many groundwater resources exceeded drinking water standards. Moreover, there is a concern regarding the contamination of water resources and its effect on people's health and the environment. Therefore, this study aims at removing nitrate ion from water using GFH.

\section{Objectives}

The main objectives of this study were to evaluate the feasibility of using GFH to remove nitrate from aqueous solution, to measure the effect of interfering ions such as sulfate and chloride on the adsorption process and to determine the removal efficiency at the optimal condition.

\section{Patients and Methods}

The adsorption experiments were carried out in triplicates at the bench-scale method. The study parameters were $\mathrm{pH}$, contact time, adsorbent dose, and initial nitrate concentration. All experiments were done on a reciprocal shaker $(300 \mathrm{rpm})$ at room temperature $\left(20^{\circ} \mathrm{C}\right)$ using $50 \mathrm{~mL}$ Erlenmeyer flask. All samples were passed through Whatman filter paper $(0.45 \mu \mathrm{m})$ and then measured using a UV spectrophotometer. Factorial design was used for the analysis of the parameters and their interaction effects were studied as well. To reduce scatter in data, log of transformation and geometric mean were used.

\subsection{Patients and Materials}

Potassium nitrate (KNO3) was purchased from a Belgian company (Kem Lab, Belgium). Granular ferric hydroxide with the specifications provided by the manufacturer (Table 1) was provided by WAS Serchemie Gmb H Company (Germany). The specifications of GFH were shown in Table 1. The rest of chemicals were purchased from Merck (Germany). Sodium hydroxide $(\mathrm{NaOH})$ and Hydrogen Chloride $(\mathrm{HCl})$ were used to adjust the $\mathrm{pH}$. The residual nitrate was measured with the standard method No. 357. The spectrophotometer (Dr5000, $\mathrm{HACH}, \mathrm{USA}$ ) at $275 \mathrm{~nm}$ was used to determine the nitrate concentration. 
Table 1. Physical and Chemical Properties of Granular Ferric Hydroxide

\begin{tabular}{lc}
\hline Ferric Oxy- Hydroxide & $\mathbf{5 2}-\mathbf{5 7 \%}$ by Weight \\
\hline Porosity, $\%$ & $72-77$ \\
pH & $7.5-8.2$ \\
Special area, $\mathbf{~ m}^{2} / \mathbf{g}$ & 280 \\
Density, $\mathbf{~ K g} / \mathbf{m}^{3}$ & 1250 \\
Effective $\mathbf{~ s i z e , ~} \mathbf{m m}$ & $0.32-2$ \\
\hline Uniformity coefficient & About 3 \\
\hline
\end{tabular}

\subsection{The Preparation of the Granular Ferric Hydrox- ide as an Adsorbent}

According to Badruzzaman et al. (22), GFH was dried in the oven at $105^{\circ} \mathrm{C}$ for 90 minutes to remove the moisture. Then, it was kept in the desiccators.

\subsection{Effects of Different Parameters on the Rate of Adsorption of Nitrate by Granular Ferric Hydroxide} To measure the influence of $\mathrm{pH}$ on the adsorption of nitrate by GFH in the aqueous solution, different $\mathrm{pH}$ at 5 levels (3.8 - 4.8 - 5.8 - 6.8 - 7.8) with three replications was used at initial concentrations (50, 75, 100, and $150 \mathrm{mg} \mathrm{NO} / \mathrm{L})$, dose of an adsorbent (GFH) at four levels (0.625, 1.25, 2.5 and $3.75 \mathrm{~g} / 50 \mathrm{~mL})$, and different contact times (30,60, and 90 minutes).

The effect of interfering ions such as sulfate at 4 levels $(200,400,600$, and $800 \mathrm{mg} / \mathrm{L})$ and chloride at 4 levels $(200,400,600$, and $800 \mathrm{mg} / \mathrm{L})$ on the removal of nitrate were investigated at the optimal condition. All the experiments were done at three replications. A blank without GFH was also used for all of the experiments. Afterwards, residual nitrate was measured. The data were analyzed using the SPSS for Windows (version 16, SPSS Inc., Chicago, IL, USA) by Pearson's correlation coefficient to analyze the relationship between these parameters.

\section{Results}

\subsection{Effects of $\mathrm{pH}$ and Contact Time on the Rate of Adsorption of Nitrate by Granular Ferric Hydroxide}

The variations of $\mathrm{pH}$ on the rate of adsorption of nitrate by GFH were shown in Figure 1. Data demonstrated that the highest removal of nitrate was at acidic $\mathrm{pH}$. According to Figure 1, the maximum removal of $60 \%$ was achieved at $\mathrm{pH}=4.8$. The Removal efficiency of nitrate was decreased at basic $\mathrm{pH}$.

According to data obtained in the current study, the maximum nitrate adsorption by GFH was at contact time of 90 minutes. Figures 2 - 4 shows the effect of initial nitrate concentration on the removal efficiency at different contact times (30, 60, and 90 minutes). The effect of different contact times on the removal efficiency of nitrate by GFH is presented in Figures 5 - 8 (at the initial nitrate concentrations of 50, 75, 100 and $150 \mathrm{mg} / \mathrm{L}$ ).

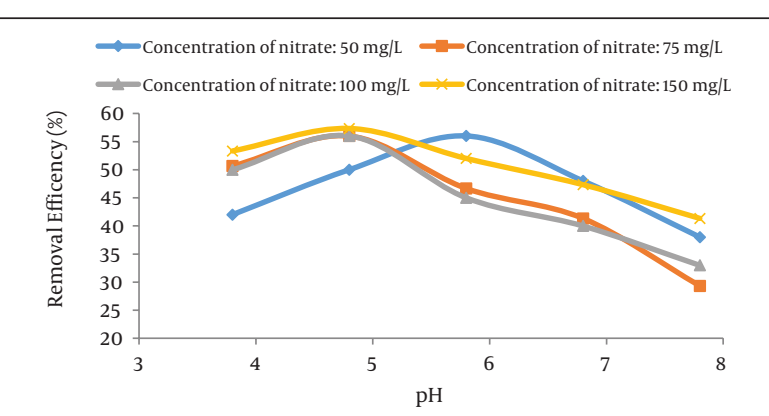

Figure 1. The Effect of $\mathrm{pH}$ on the Removal Efficiency of Nitrate by Granular Ferric Hydroxide

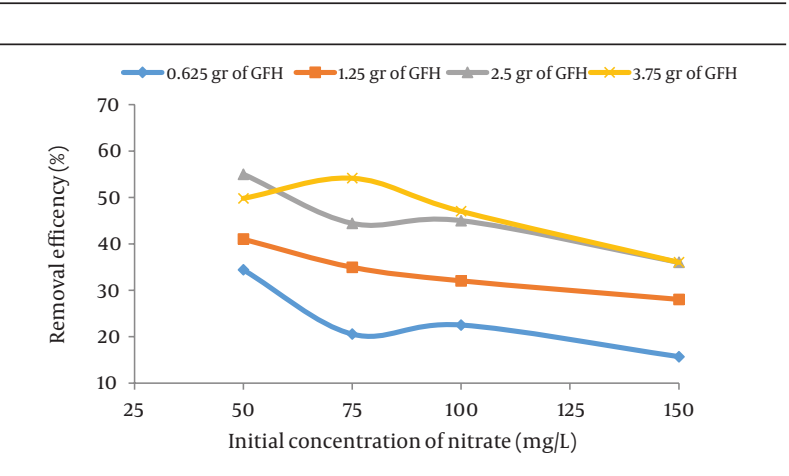

Figure 2. The Effect of Nitrate Initial Concentrations on the Removal Efficiency of Nitrate by Granular Ferric Hydroxide at 30 Minutes Contact Time

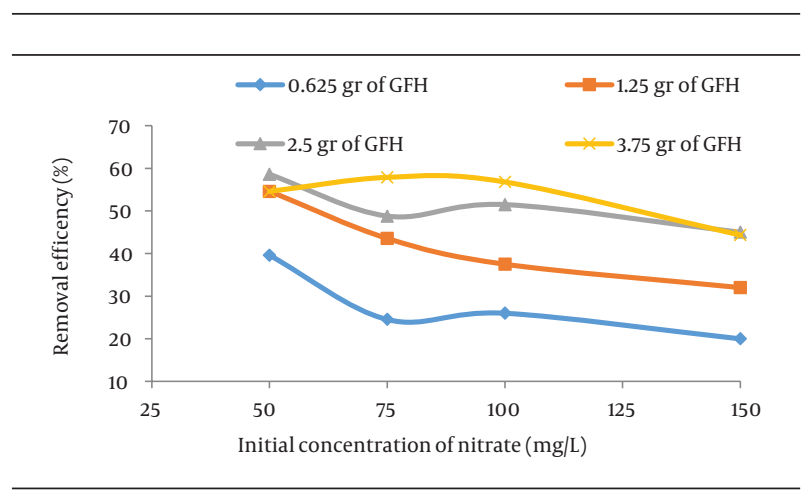

Figure 3. The Effect of Nitrate Initial Concentrations on the Removal Efficiency of Nitrate by Granular Ferric Hydroxide at 60 Minutes Contact Time

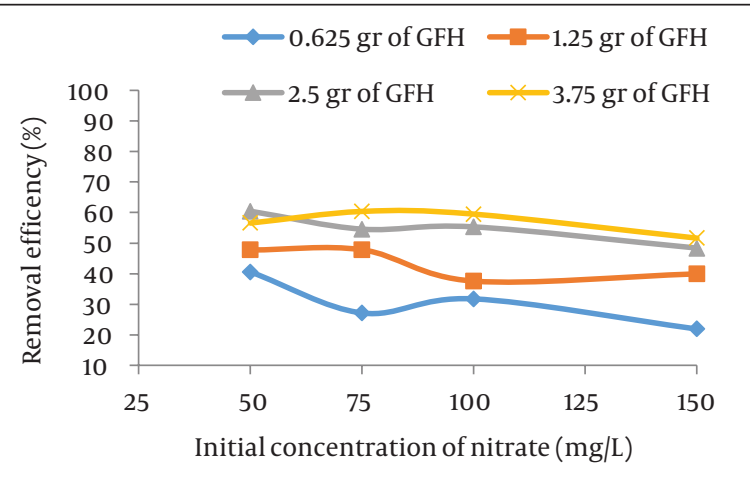

Figure 4. The Effect of Nitrate Initial Concentration on the Removal Efficiency of Nitrate by Granular Ferric Hydroxide at 90 Minutes Contact Time 
Dehghani M et al.

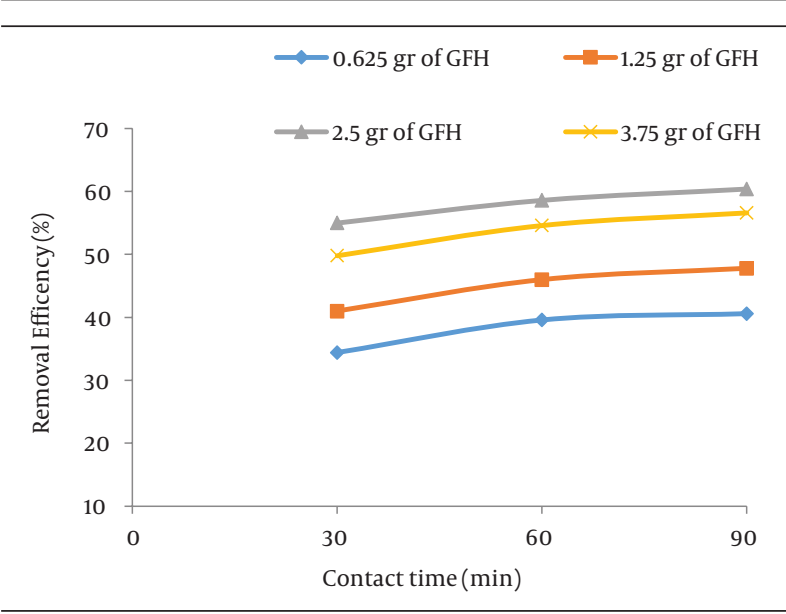

Figure 5. The Effect of Contact Time on the Removal Efficiency of Nitrate by Granular Ferric Hydroxide at Initial Concentration $(50 \mathrm{mg} / \mathrm{L}$ )

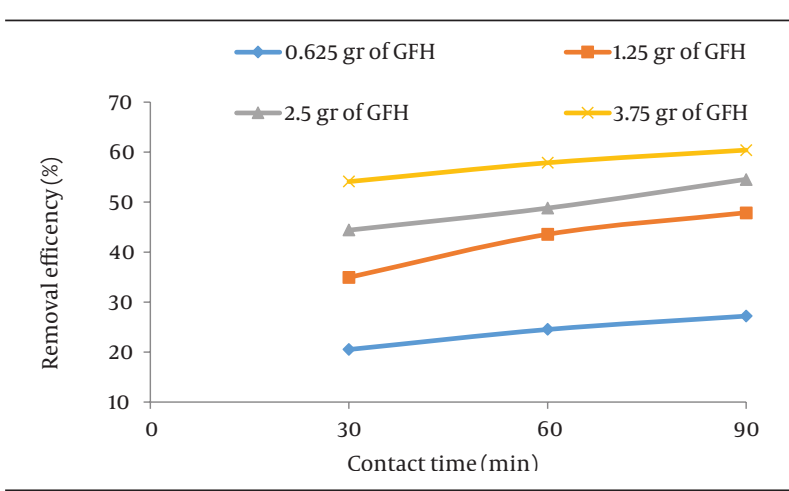

Figure 6. The Effect of Contact Time on the Removal Efficiency of Nitrate by Granular Ferric Hydroxide at Initial Concentration $(75 \mathrm{mg} / \mathrm{L})$

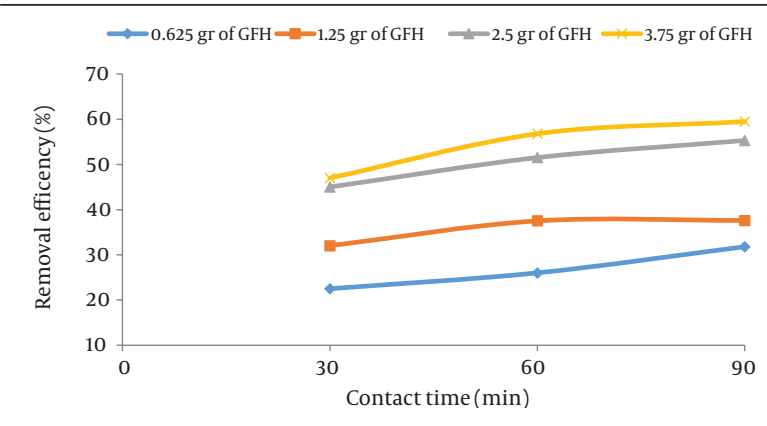

Figure 7. The Effect of Contacting Time on Removal Efficiency by Granular Ferric Hydroxide in Nitrate Initial Concentration $(100 \mathrm{mg} / \mathrm{L})$

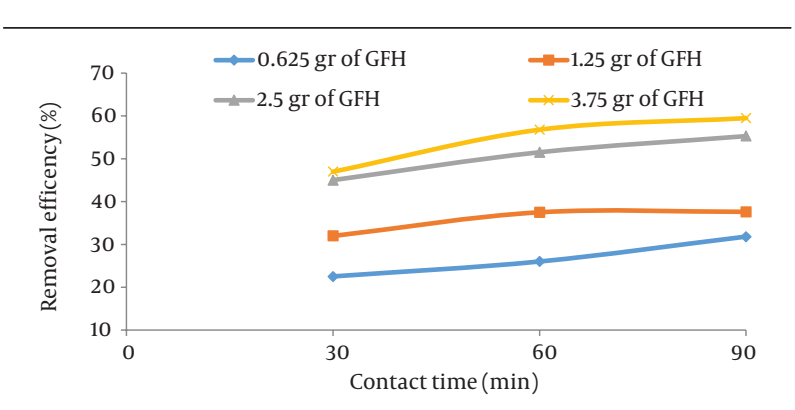

Figure 8. The Effect of Contact Time on the Removal Efficiency of Nitrate by Granular Ferric Hydroxide at Initial Concentration $(150 \mathrm{mg} / \mathrm{L})$
According to Figure 2, nitrate adsorption rate decreased from $56 \%$ to $36 \%$ as the initial nitrate concentration increased from 50 to $150 \mathrm{mg} / \mathrm{L}$. According to Figures 9 -12, a nitrate adsorption rate increased as the applied adsorbent dose of GFH increased $(0.625,1.25,2.5$, and $3.75 \mathrm{~g}$ ). The maximum and minimum adsorption rates were $60 \%$ and $22 \%$ at the adsorbent doses of 3.75 and $0.625 \mathrm{~g}$, respectively.

The effects of different concentrations of interfering ions (sulfate and chloride) on the removal efficiency of nitrate by GFH at different initial nitrate concentrations are presented in Tables 2 - 5. In addition, the efficiency rates

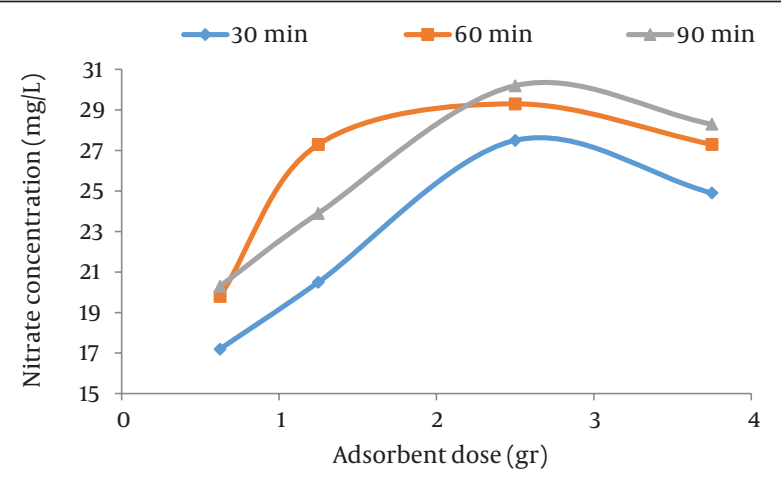

Figure 9. The Effect of Adsorbent (Granular Ferric Hydroxide) Dose on the Removal Efficiency of Nitrate at Initial Nitrate Concentration $(50 \mathrm{mg} / \mathrm{L})$

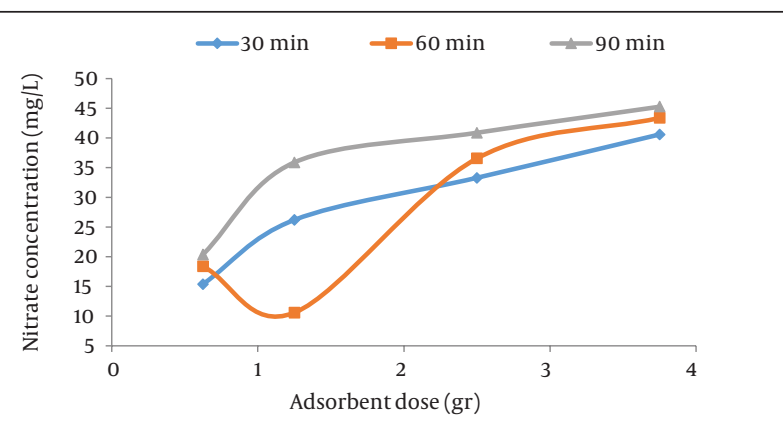

Figure 10. The Effect of Adsorbent (Granular Ferric Hydroxide) Dose on the Removal Efficiency of Nitrate at Initial Nitrate Concentration $(75 \mathrm{mg} / \mathrm{L})$

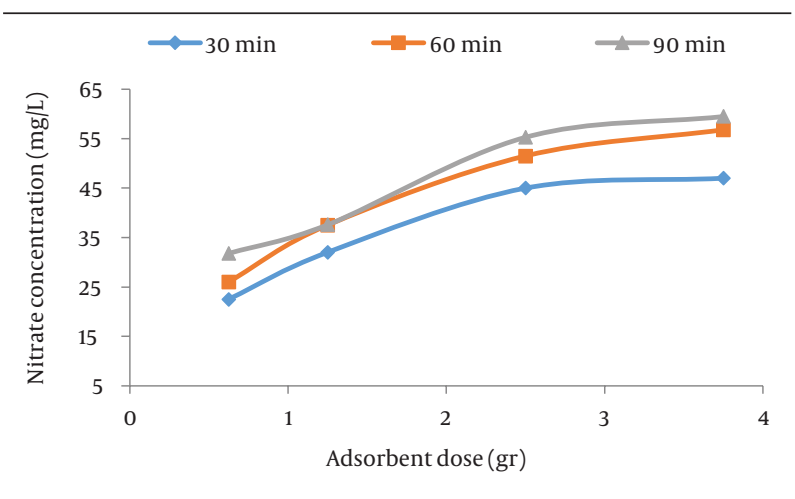

Figure 11. The Effect of Adsorbent (Granular Ferric Hydroxide) Dose on the Removal Efficiency of Nitrate at Initial Nitrate Concentration $(100 \mathrm{mg} / \mathrm{L})$ 
of GFH in the samples taken from groundwater (nitrate concentration was close to the amount of nitrate in the synthetic samples) were evaluated at the optimal conditions (contact time of 90 minutes, adsorbent dose $=3.75$ g) (Figure 13).

According to the results, the removal of nitrate in groundwater was $31 \%$ lower than the synthetic samples.

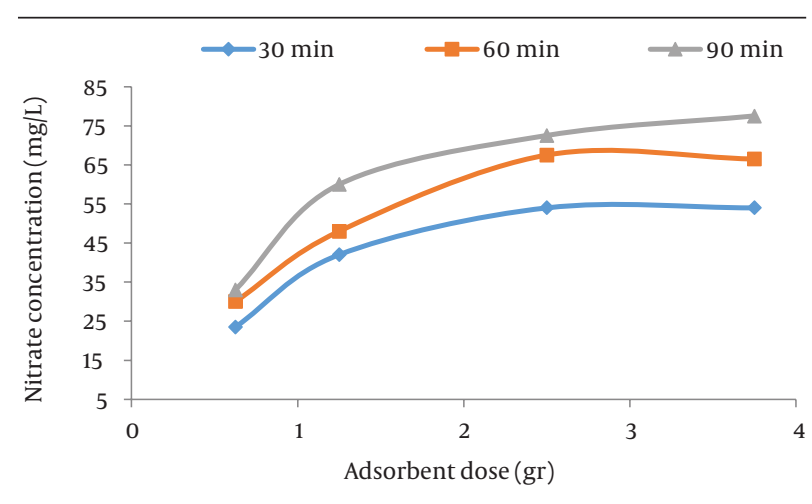

Figure 12. The Effect of Adsorbent (Granular Ferric Hydroxide) Dose on the Removal Efficiency of Nitrate at Initial Nitrate Concentration $(150 \mathrm{mg} / \mathrm{L})$

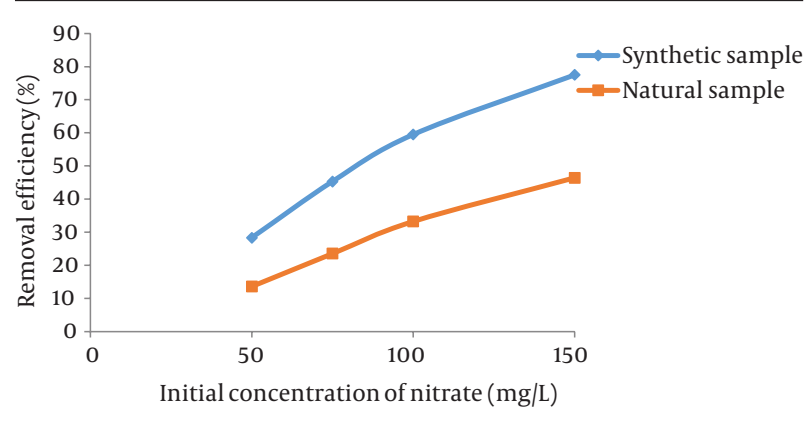

Figure 13. The Comparison of Nitrate Removal Efficiency of Natural Groundwater and Synthetic Samples at the Optimal Condition by Granular Ferric Hydroxide

\section{Discussion}

$\mathrm{pH}$ is an important parameter for the removal of pollutants by the adsorption process (30). Also, the $\mathrm{pH}$ level controls the adsorption process due to the electrostatic force between the adsorbent and adsorbate (31). According to Figure 1, the optimum $\mathrm{pH}$ for nitrate adsorption by GFH is in the range of 4.8 to 5.8 due to the improvement of adsorption capacity of GFH in an acidic medium (32).

The nitrate adsorption rate decreased at $\mathrm{pH}$ more than 5.8. This could be due to the formation of oxygen-containing compounds on the surface of GFH. The formation of these groups on the surface of the adsorbent reduced the accessibility of nitrate to adsorption sites which caused the nitrate adsorption significantly reduced (33). Similar results also have been reported by Asgari et al. (28). One study showed that by increasing $\mathrm{pH}$ from 3 to 11 the ni- trate removal efficiency decreased from $98.8 \%$ to $23.6 \%$, respectively (6). According to the regression analysis, it can be concluded that there was a significant difference between the $\mathrm{pH}$ level and nitrate adsorption rate $(\mathrm{P}<0.001)$. The effect of $\mathrm{pH}$ on the removal of adsorbate was depended on the pH of zero point of charge ( $\mathrm{pHzpc}$ ) of adsorbent. The GFH surface had positive charge at $\mathrm{pH}$ less than the pHzpc of GFH. Similarly, the GFH surface had negative charge at $\mathrm{pH}$ was above the $\mathrm{pHzpc}$ of GFH. The point of zero point charge (pHzpc) was between 7.5 and 8.0 (34).

One of the most important parameters in the adsorption process is determining the equilibrium time to achieve the maximum adsorption of nitrate from aqueous solution.

According to the results illustrated in Figures 2 - 4, at first the adsorption rate of nitrate increased rapidly as the contact time increased from 30 to 60 minutes. Afterwards, its rate slowed down (60 - 90 minutes). This phenomenon may be related to the presence of many vacant adsorption sites on the adsorbent surface. The remaining sites were not easily accessible for the target molecules. Therefore, it can be concluded that the high reduction of nitrate by GFH at the beginning of the adsorption process might be due to the presence of many available vacant adsorption sites for the adsorption. Regression analysis showed that there was a significant difference between the contact time and nitrate adsorption rate $(\mathrm{P}<0.001)$. The adsorption rate is basically controlled by the migration rate of the contaminant (35). This phenomenon was also reported by many other studies (24-26). Dehghani et al. also found that the adsorption kinetics of atrazine in soil had an initial steep slope reaching a plateau with a relative slow equilibration $(9,32)$.

The initial concentration of the contaminant is effective on the adsorption capacity. Also, the initial concentration has a significant role in overcoming mass transfer resistance of the adsorbate between liquid and solid phases (31). Regression analysis showed that there was a significant difference between the initial nitrate concentration and nitrate adsorption removal rate $(\mathrm{P}<0.001)$. Data demonstrated that as the initial nitrate concentration increased, the rate of adsorption reduced. Higher available binding sites in the adsorbent may result in a higher rate of nitrate adsorption. Our results are in agreement with other studies $(23-25,36)$.

According to the findings of the current study, the adsorbent dose is an important parameter for the adsorption rate. Figures 10 - 12 depict that nitrate removal depended on the adsorbent dose in the solution. According to regression analysis, it can be concluded that there was a significant difference between adsorbent dose and nitrate adsorption removal rate $(\mathrm{P}<0.001)$. The result showed that as the adsorbent concentration increased, the percentage of nitrate removal increased as well. The same results were obtained by other studies (24).

Tables 2 - 5 showed the significant effect of interfering ions (sulfate and chloride ions) on the removal efficiency 
Table 2. The Effect of Interfering Ions on the Removal Efficiency of Nitrate by Granular Ferric Hydroxide at Initial Nitrate Concentration $(50 \mathrm{mg} / \mathrm{L})^{\text {a }}$

\begin{tabular}{|c|c|c|c|c|c|c|c|}
\hline $\begin{array}{l}\text { Interfering } \\
\text { Ions, } \mathbf{m g} / \mathbf{L}\end{array}$ & $\begin{array}{c}\text { Without } \\
\text { Interfering Ions }\end{array}$ & $\mathrm{SO}_{4}=200, \mathrm{Cl}=200$ & $\mathrm{SO}_{4}=\mathrm{o}, \mathrm{Cl}=\mathbf{4 0 0}$ & $\mathrm{SO}_{4}=400, \mathrm{Cl}=\mathrm{O}$ & $\mathrm{SO}_{4}=\mathrm{O}, \mathrm{Cl}=600$ & $\mathrm{SO}_{4}=\mathrm{O}, \mathrm{Cl}=\mathbf{8 0 0}$ & $\mathrm{SO}_{4}=600, \mathrm{Cl}=\mathrm{o}$ \\
\hline $\begin{array}{l}\text { Removal } \\
\text { efficiency, \% }\end{array}$ & 56.6 & 17.2 & 15.8 & 19 & 14.8 & 16.6 & 13.4 \\
\hline
\end{tabular}

Table 3. The Effect of Interfering Ions on the Removal Efficiency of Nitrate by Granular Ferric Hydroxide at Initial Nitrate Concentra$\operatorname{tion}(75 \mathrm{mg} / \mathrm{L})^{\text {a }}$

\begin{tabular}{|c|c|c|c|c|c|c|c|}
\hline $\begin{array}{l}\text { Interfering Ions, } \\
\mathrm{mg} / \mathrm{L}\end{array}$ & $\begin{array}{c}\text { Without } \\
\text { Interfering Ions }\end{array}$ & $\mathrm{SO}_{4}=200, \mathrm{Cl}=\mathbf{2 0 0}$ & $\mathrm{SO}_{4}=\mathrm{o}, \mathrm{Cl}=400$ & $\mathrm{SO}_{4}=400, \mathrm{Cl}=\mathrm{O}$ & $\mathrm{SO}_{4}=\mathbf{0}, \mathrm{Cl}=600$ & $\mathrm{SO}_{4}=\mathbf{0}, \mathrm{Cl}=\mathbf{8 0 0}$ & $\mathrm{SO}_{4}=600, \mathrm{Cl}=\mathrm{o}$ \\
\hline $\begin{array}{l}\text { Removal } \\
\text { efficiency, \% }\end{array}$ & 60.4 & 28.5 & 14.9 & 17.3 & 7.4 & 15.7 & 10.9 \\
\hline
\end{tabular}

a Abbreviations: $\mathrm{Cl}$, chloride; . $\mathrm{SO}_{4}$, sulfate.

Table 4. The Effect of Interfering Ions on the Removal Efficiency of Nitrate by Granular Ferric Hydroxide at Initial Nitrate Concentration $(100 \mathrm{mg} / \mathrm{L})^{\text {a }}$

\begin{tabular}{|c|c|c|c|c|c|c|c|}
\hline $\begin{array}{l}\text { Interfering } \\
\text { Ions, mg/L }\end{array}$ & $\begin{array}{c}\text { Without } \\
\text { Interfering Ions }\end{array}$ & $\mathrm{SO}_{4}=200, \mathrm{Cl}=\mathbf{2 0 0}$ & $\mathrm{SO}_{4}=\mathrm{O}, \mathrm{Cl}=\mathbf{4 0 0}$ & $\mathrm{SO}_{4}=400, \mathrm{Cl}=\mathrm{O}$ & $\mathrm{SO}_{4}=\mathbf{0}, \mathrm{Cl}=600$ & $\mathrm{SO}_{4}=\mathrm{o}, \mathrm{Cl}=\mathbf{8 0 0}$ & $\mathrm{SO}_{4}=600, \mathrm{Cl}=\mathrm{O}$ \\
\hline $\begin{array}{l}\text { Removal } \\
\text { efficiency, \% }\end{array}$ & 59.5 & 13.5 & 2 & 18 & 2.5 & 13 & 8.1 \\
\hline
\end{tabular}

Table 5. The Effect of Interfering Ions on the Removal Efficiency of Nitrate by GFH at Initial Nitrate Concentration (150 mg/L) ${ }^{a}$

\begin{tabular}{|c|c|c|c|c|c|c|c|}
\hline $\begin{array}{l}\text { Interfering Ions, } \\
\mathrm{mg} / \mathrm{L}\end{array}$ & $\begin{array}{c}\text { Without } \\
\text { Interfering Ions }\end{array}$ & $\mathrm{SO}_{4}=200, \mathrm{Cl}=200$ & $\mathrm{SO}_{4}=\mathrm{o}, \mathrm{Cl}=\mathbf{4 0 0}$ & $\mathrm{SO}_{4}=400, \mathrm{Cl}=\mathrm{O}$ & $\mathrm{SO}_{4}=\mathbf{0}, \mathrm{Cl}=\mathbf{6 0 0}$ & $\mathrm{SO}_{4}=\mathrm{o}, \mathrm{Cl}=\mathbf{8 0 0}$ & $\mathrm{SO}_{4}=600, \mathrm{Cl}=\mathrm{o}$ \\
\hline $\begin{array}{l}\text { Removal } \\
\text { efficiency, \% }\end{array}$ & 51.6 & 38.6 & 22.6 & 19 & 23.3 & 0.6 & 26 \\
\hline
\end{tabular}

a Abbreviations: $\mathrm{Cl}$, chloride; . $\mathrm{SO}_{4}$, sulfate.

of nitrate by GFH. Data showed that both sulfate and chloride ions had an effect on the removal of nitrate. In fact, as the concentration of interfering ions was increased, the removal of nitrate was decreased. According to data obtained in this study, the interference of chloride ions was more than sulfate ions. One study showed that the fluoride adsorption in presence of phosphate, carbonate and sulfate ions was remarkably reduced (27).

Figure 13 indicates that there was no considerable difference between the removal rate of nitrate in synthetic and natural (groundwater) water samples (at optimal adsorbent dose and contact time). Therefore, this method has a high capability for the removal of nitrate in water resources with high nitrate concentration.

In conclusion, the result revealed that nitrate in liquid solution was effectively retained by the GFH adsorbent. The rate of nitrate adsorption showed an initial increase, reaching a plateau with a relative slow rate. The adsorption of nitrate was increased with decreasing the initial concentration of nitrate and increased with the adsorbent dose. The nitrate adsorption in the aqueous solution was optimal at $\mathrm{pH}=4.8$ and contact time of 90 minutes. The results showed that the maximum removal of nitrate from aqueous solutions at the optimum conditions is more than $60 \%$. The removal of nitrate in the groundwater samples obtained from rural wells near Shiraz vicinity (with nitrate concentration of $18 \mathrm{mg} / \mathrm{L}$ ) was $46 \%$. According to data obtained in the current study, the level of nitrate concentration using GFH did not exceed the standard limit for drinking water. Therefore, GFH can be used as an efficient, cost-effective and easily conducted method to remove nitrate from water resources. We highly recommend that the study should be conducted for dynamic column testing using GFH to remove nitrate from different background water qualities. It is also suggested that the concentration of iron in drinking water should be determined. Moreover, it is highly suggested that the used absorbent should be evaluated for the feasibility of recovery and reuse of GFH.

\section{Acknowledgements}

The authors would like to thank the deputy of Research and Technology of Shiraz University of Medical Sciences 
for supporting the research project 7905. Also, we appreciate Dr. Shokrpour at center for development of clinical research in Nemazee Hospital for editorial assistance.

\section{Financial Disclosure}

This study was funded by Shiraz University of Medical Sciences.

\section{Funding/Support}

This study was funded by the deputy of research and technology of Shiraz University of Medical Sciences for supporting the research project 7905.

\section{References}

1. Torabian AS, Hassani A, Abedi Samak M. Comparing reverse osmosis and ion exchange methods of nitrate elimination. J Environ Sci Technol . 2006;8:21-8.

2. Cho DW, Chon CM, Jeon BH, Kim Y, Khan MA, Song H. The role of clay minerals in the reduction of nitrate in groundwater by zerovalent iron. Chemosphere. 2010;81(5):611-6.

3. Gray NF. [Drinking water quality, problems and solutions. Volume 1] Translated by Jafarzadeh Haghighifard N Qotbi Sh Asgari A Yarahmadi M,Tehran: Khaniran.

4. Izanlu H, Rahimi H, Mahmudian M, Khazae M. Nitrate removal from water using absorbent granular ferric hydroxide. $J$ Health Sys Res. 2010;6:952-9.

5. Mohammadnia M, Kowsar SA. Clay Translocation in the Artificial Recharge of a Groundwater System in the Southern Zagros Mountains, Iran. Mt Res Dev. 2003;23(1):50-5.

6. Samarghandi MR, Golzar Khojasteh B. Application of Photo-Fenton Process For the removal of Nitrate from Aqueous Solutions. JundishapurJ Health Sci. 2013;5(2):99-106.

7. El-Sofany EA. Removal of lanthanum and gadolinium from nitrate medium using Aliquat-336 impregnated onto Amberlite XAD-4. J Hazard Mater. 2008;153(3):948-54.

8. United States Environmental Protection Agency.. Water: Basic Information about Regulated Drinking Water Contaminants Basic Information about Regulated Drinking Water Contaminants and Indicators. 2013. Available from: http://water.epa.gov/drink/contaminants/basicinformation/.

9. Dehghani $M$, Haghighi $A B$, Zamanian $Z$. The efficiency of Amberjet 4200 resin in removing nitrate in the presence of competitive anions from Shiraz drinking water. Pak J Biol Sci. 2010;13(11):551-5.

10. Schoeman JJ, Steyn A. Nitrate removal with reverse osmosis in a rural area in South Africa. Desalination. 2003;155(1):15-26.

11. Clauwaert P, Rabaey K, Aelterman P, de Schamphelaire L, Pham $\mathrm{TH}$, Boeckx P, et al. Biological denitrification in microbial fuel cells. Environ Sci Technol. 2007;41(9):3354-60.

12. Lacasa E, Cañizares P, Sáez C, Fernández FJ, Rodrigo MA. Removal of nitrates from groundwater by electrocoagulation. Chem Eng J. 2011;171(3):1012-7.

13. Chungsying L, Fengsheng S. Adsorption of natural organic matter by carbon nanotubes. Sep Purif Technol. 2007;58(1):113-21.

14. Langmuir I. The Constitution and Fundamental Properties of Solids and Liquids. Part I. Solids. J Am Chem Soc. 1916;38(11):2221-95.

15. Vergili I, Barlas H. Removal of 2, 4-D, MCPA and Metalaxyl from water using Lewatit VP OC 1163 as sorbent. Desalination. 2009;249(3):1107-14.

16. Hameed BH, Ahmad AL, Latiff KNA. Adsorption of basic dye (methylene blue) onto activated carbon prepared from rattan sawdust. Dyes and Pigments. 2007;75(1):143-9.

17. Hameed BH, Din AT, Ahmad AL. Adsorption of methylene blue onto bamboo-based activated carbon: kinetics and equilibrium studies.J Hazard Mater. 2007;141(3):819-25.

18. Saeedi M, Abbas J, Bayat M. Removal of water-insoluble cadmium by adsorption on carbon from walnut and almond bark; compared with granular activated carbon. J Water waste water. 2009:16-21.

19. Malakootian M, YAGHMAIAN K, Tahergorabi M. The Efficiency of Nitrate Removal in Drinking Water Using Iron Nano-Particle: Determination of Optimum Conditions. J Yazd Univ Med Sci. 2011;10(2011):35-44.

20. Demiral H, Gunduzoglu G. Removal of nitrate from aqueous solutions by activated carbon prepared from sugar beet bagasse. Bioresour Technol. 2010;101(6):1675-80.

21. Asgari AR. Study of the Efficiency of Arsenic Removal from Drinking Water by Granular Ferric Hydroxide (GFH). Qom Univ Med Sci J. 2008;2(1):53-62.

22. Badruzzaman M, Westerhoff P, Knappe DR. Intraparticle diffusion and adsorption of arsenate onto granular ferric hydroxide (GFH). Water Res. 2004;38(18):4002-12.

23. Askari A, Mahvi A, Vaezi F, Ghasri A. Granular ferric hydroxide (GFH) an adsorbent for removal of arsenate and arsenite from drinking water. Sci J Kordestan Univ Med Sci. 2008;8:76-86.

24. Karimi B, Rajai M, Ghanadzadeh M, Mashayekhi M, Jahanbakhsh $\mathrm{M}$. Removal of nitrate from water by adsorption on activated carbon process and $\mathrm{Fe} / \mathrm{H} 2 \mathrm{O} 2$. J Arak Univ Med Sci. 2012;9:67-76.

25. Shahmorady M, Aminzadeh B, Torabian AS, editors. Ground water nitrate removal using activated carbon obtained from rice; In Proceedings of the First National Conference on strategies for achieving sustainable development.; 2012; Tehran. Ministry of Interior;

26. Thirunavukkarasu OS, Viraraghavan T, Subramanian KS. Arsenic removal from drinking water using granular ferric hydroxide. WaterSa. 2003;29(2):161-70.

27. Kumar E, Bhatnagar A, Ji M, Jung W, Lee SH, Kim SJ, et al. Defluoridation from aqueous solutions by granular ferric hydroxide (GFH). Water Res. 2009;43(2):490-8.

28. Asgari AR, Vaezi F, Nasseri S, Dördelmann O, Mahvi AH, Fard ED. Removal of hexavalent chromium from drinking water by granular ferric hydroxide. Iran J Environ Health Sci Eng. 2008;5(4):277-82.

29. Boels L. Removal and recovery of phosphonate antiscalants.Delft: Delft University of Technology; 2012.

30. Aksu Z, Yener J. A comparative adsorption/biosorption study of mono-chlorinated phenols onto various sorbents. Waste Manag. 2001;21(8):695-702.

31. Anbia M, Ghaffari A. Adsorption of phenolic compounds from aqueous solutions using carbon nanoporous adsorbent coated with polymer. Applied Surface Science. 2009;255(23):9487-92.

32. Shahsavari AA, Khodaei K, Asadian F, Ahmadi F, Zamanzadeh SM. Groundwater pesticides residue in the southwest of Iran-Shushtar plain. Environ Earth Sci. 2011;65(1):231-9.

33. Peng X, Li Y, Luan Z, Di Z, Wang H, Tian B, et al. Adsorption of 1,2-dichlorobenzene from water to carbon nanotubes. Chem Phys Lett. 2003;376(1-2):154-8.

34. Huo L, Yang Q, Shang H. Kinetics and thermodynamic study of nitrate adsorption on granular ferric hydroxide. Fresenius Environ Bull. 2012;21:789-96.

35. Ayar N, Bilgin B, Atun G. Kinetics and equilibrium studies of the herbicide 2, 4-dichlorophenoxyacetic acid adsorption on bituminous shale. Chem EngJ. 2008;138(1):239-48.

36. Dehghani M, Nasseri S, Amin S, Naddafi K, Yunesian M, Maleki MTN. Atrazine adsorption-desorption behavior in Darehasaluie Kavar corn field soil. Iranian Journal of Environmental Health Science \& Engineering. 2005;2(4):221-8. 